\title{
Effect of processing techniques on the overall quality attributes of cookies produced from jackbeans and wheat flour
}

\author{
O. A. Idowu' ${ }^{1}$ and A. O. Akinsola ${ }^{1,2^{*}}$ \\ ${ }^{1}$ Department of Food Technology, Federal Polytechnic, Offa, Kwara State, Nigeria \\ ${ }^{2}$ Department of Home Economics, Federal College of Education (Special), Oyo, Oyo State, Nigeria
}

\begin{abstract}
The study was carried out to determine the effectiveness of heat processing on jackbeans, an underutilized legume. Raw and processed seed flour (roasted at $1200 \mathrm{C}$ for $10 \mathrm{mins}$ and pressure cooked for 10mins) produced from jackbeans were evaluated for its nutritional quality and antinutritional factors using standard methods. The nutritional qualities determined showed that sample with 20\% pressure cooked jackbeans flour supplement has the highest amount of protein, fat, fibre and ash content, while the sample with $40 \%$ supplementation of pressure cooked jackbeans flour has the highest percentage of moisture content. The cookies produced from $100 \%$ wheat flour has the highest percentage of carbohydrate, while sample with $40 \%$ roasted jackbeans flour supplement has the highest percentage of concanavanine A. The antinutritional factors of the processed flours were found to be lower than the raw seed flour. Sensory qualities determined showed that sample with $20 \%$ of pressure cooked jackbeans supplement was rated high in terms of taste, aroma, texture, and overall acceptability, while cookies with $100 \%$ wheat flour was rated high 7.7 in term of colour. This study showed that thermal processing especially pressure cooking decreased the antinutritional contents of the jackbeans flour than other processing methods used.
\end{abstract}

Key words: Jackbeans; antinutritional factors; pressure cooked jackbeans; concanavanine A

\section{Introduction}

The demand for protein rich food is constantly increasing worldwide, especially in developing nations, due to the population increase and diminishing agricultural production. Although cereal grains served in this aspect, still the demand is not met with in most of the countries, which leads to the option of alternative high costly sources for energy nutrition (Sridhar and Seena 2006). Main sources of protein rich foods are leguminous plants (Bressani, 2002). Jackbeans (Canavalia ensiformis) is an important, but under exploited beans, the seed contains about
$300 \mathrm{~g} / \mathrm{kg}$ crude protein and $600 \mathrm{~g} / \mathrm{kg}$ carbohydrate (Udedibie and Nkwocha, 1990). The intended use of Jack beans flour for the production of cookies is to increase the use of the beans and enhance food security in children and adults in tropical regions. Composite flour produced from cereals and legumes such as wheat flour and jackbeans flour have the advantage of improving overall nutrition (FAO, 1995). In selecting the components to be used preferably it should be readily available, culturally acceptable and provide increased nutritional potential (Akobundu et al., 1998).

\section{Received 18 November 2017; Accepted 29 December 2017; Published 31 December 2017}

*Corresponding Author

A. O. Akinsola

Department of Food Technology, Federal Polytechnic, Offa, Kwara State, Nigeria

Email: akinsola4gold@gmail.com

(CThis article is open access and licensed under the terms of the Creative Commons Attribution License (http://creativecommons.org/licenses/by/4.o/) which permits unrestricted, use, distribution and reproduction in any medium, or format for any purpose, even commercially provided the work is properly cited. Attribution - You must give appropriate credit, provide a link to the license, and indicate if changes were made. 
The consumption of cereal based foods like cookies require the development of an adequate substitute that would be readily available, cheap, and able to replace wheat flour in terms of its functionality (Hussain et al., 2006). Cookies are mainly produced from hard wheat flour (Triticum spp) and different techniques are used for the production. These methods are either the mixing method, which is involves the sieving of flour, baking powder, and nutmeg (dry ingredients), sugar and margarine of a known weight together and mixed thoroughly, beaten eggs were added; and also the sifted dry ingredients were added and mixed together to produce batter. The batter is rolled out on a rolling board to $0.5 \mathrm{~cm}$ height and cut into shape. The cookies are now baked in a pre-heated electric oven; cookies were produced from the composite flour of wheat flour and jackbeans flour.

Jackbeans flour cannot be used all alone in the production of cookies, because it lacks gluten which is responsible for risen up of flour in any pastry production; so wheat flour has to be added to produce composite flour which is used for cookies production and other baked products. In view of the above, the objectives of this study were to determine the effect of different processing techniques on the antinutritional factors and the proximate composition of jackbeans, and also to determine the overall quality attributes of cookies produced from composite flour of processed jackbeans and wheat flour.

\section{Materials and method}

The matured seeds were obtained from International Institute of Tropical Agriculture IITA, Ibadan and was planted in the Federal Polytechnic Offa, experimental farm in May 2014. The beans were matured and harvested in December 2015. Other ingredients for cookies production were obtained from Owode market, Offa, Kwara State.

\section{Preparation of samples \\ Raw (Control) samples}

The raw samples were dried in the sun and broken by the use of mortar and pestle to remove the seed coats. The seed were milled, sieved and packaged in an air tight container for further use.

\section{Roasting method}

The roasting method was carried out by the use of sand bath which was pre heated to temperature of $120^{\circ} \mathrm{C}$ and $1 \mathrm{~kg}$ of jackbeans seed was introduced which was roasted for 10 minutes. The jackbeans were removed and allowed to cool to room temperature, roasted seeds were dehulled, milled (attrition milling), sieved using $1 \mathrm{~mm}$ mesh size and packaged in an air tight container until required for use.

\section{Pressure cooking method}

The pressure cooking was carried out by the use of household pressure cooker (Crown star) Master chef No MC-PC 7005 in 1:3 (w/v) distilled water. One kilogram of the jackbeans seeds was weighed and pressure cooked for 10 minutes, cooled, dehulled, dried in a hot air oven at $55^{\circ} \mathrm{C}$ for $6 \mathrm{hrs}$, milled using attrition mill, sieved and package in an air tight container until it is require for use.

\section{Analysis for Jack beans flour}

The proximate analysis (protein, moisture content, crude fibre, ash, crude lipid) was determined using the approved AOAC method (2000) while carbohydrate was calculated by difference.

\section{Anti- nutritional content determination}

Heamagglutinin activity of jack beans flour was determined based on Liner (1953) method, while trypsin inhibitor activity was done according to the procedure described by Kakade et al. (1974). Tannin content was determined according to AOAC (2000). Phenolics and concanavalin A contents were determined as described below.

\section{Phenolics content}

Phenolics content was analysed from sample by following AOAC (1984) and as described by Mako (2013).

\section{Concanavalin A determination}

$1 \mathrm{~g}$ of flour was weighed into a $50 \mathrm{ml}$ digestion tube, $20 \mathrm{ml}$ of $6 \mathrm{MHCl}$ was added and allow to digest by placing in the digestion hole of Tecator BD 30 digestion unit to homogenize the sample to clear filtrate. The digest was allowed to cool and was filtered into $100 \mathrm{ml}$ volumetric flask up to mark with double distilled water. $1 \mathrm{ml}$ of the filtrate was pipette into a $20 \mathrm{ml}$ test tube, $0.5 \mathrm{ml}$ of phosphate buffer and $0.5 \mathrm{ml}$ of aqueous sodium nitroprussiate solution were added. Working standard solution of concanavanine A of range of 0-5ppm were prepared from stock $25 \mathrm{ppm}$ concanavaline a solution was treated similarly with phosphate buffer and sodium nitroprussiate solution. The mixture was stirred vigorously and stored in a dark cabinet 
for 2 hrs to a reddish colour indicating the presence of concanavaline A was obtained. After 2hours the absorbance of sample extract and working standard against blank were read on a spectronic 2ID spectrophotometer at a wavelength of a $520 \mathrm{~nm}$.

\section{Cookies production}

Cookies were produced based on AACC (2000) method with some modification. 250gm of flour (composite flour) sugar 125g, hydrogenated fat 12g, 1 egg (each 6og) and $5 \mathrm{gm}$ of baking powered. The cookies were produced by the process of weighing accurately the ingredients, whereby fat and sugar were mixed until fluffy, whole eggs was added and dry ingredient (baking powder, nutmeg) where added together and mixed thoroughly with the use of a dough mixer. The dough was rolled out using a $0.5 \mathrm{~cm}$ height rolling board and cut into shape with aid of a cookie cutter. The oven was pre-heated at the temperature of $190^{\circ} \mathrm{C}$ for $3-4$ min and baking was carried out at $185^{\circ} \mathrm{C}$ for 10 min. The cookies sample after production were allowed to cool to room temperature and stored in an air tight container. Cookies made from whole wheat flour serves as the control.

\section{Cookies quality parameters Physical analysis}

The physical analysis of the cookies was determined based on AACC (2000) method includes the following: spread factor, diameter (width) and thickness (height).

Spread factor (SF) was determined from the diameter and thickness as following: Calculation

$$
\mathrm{S} . \mathrm{F}=\frac{\mathrm{DXXFX10}}{\mathrm{T}}
$$

Where $\mathrm{CF}=$ correction factor at constant atmospheric pressure, is 1.0, $\mathrm{D}=$ diameter (width)

$\mathrm{T}=$ thickness. The diameter and thickness of cookies were determined in $\mathrm{mm}$ with venial caliper. This process was repeated thrice (3x) to get an average value of the result which was reported in $\mathrm{mm}$.

\section{Nutritional qualities of cookies produced \\ Proximate composition analysis}

The proximate composition of cookies produced was carried out (moisture content, fibre, crude protein, fibre, and ash content) according to AOAC method 2000 and the carbohydrate was calculated by difference.

\section{Statistical Analysis}

All data were statistically analyzed using SPSS version 17.0 for analysis of variance, while Duncan multiple range test (DMRT) was used to separate means where there is a significant difference. For each sample, triplicate determinations were carried out.

\section{Results and discussions}

The data presented in Table 1 showed the proximate composition of jackbeans flour. The crude protein of roasted jackbeans flour was found to be higher (18.63) than the pressure cooked jackbeans flour (16.73). This may be due to the fact that roasting would concentrate the nutrients present in the food as the water molecule are evaporated or volatilized out; on the other hand, the pressure cooked seed has a reduced protein content which may be due to the breaking down of protein coupled with leaching effect of water on cooking. The crude fibre of the pressure cooked flour was found to be lesser (1.84) than that of raw and roasted flour (2.07 and 1.99). Low crude fibre is nutritionally appreciated because it traps less protein and carbohydrate (Balogun \& Fetuga, 1986). The fat content was found to be higher in roasted jackbeans flour (1.96) than the pressure cooked and raw flour (1.70 and 1.88) respectively. The ash content of raw and roasted jackbeans flour were higher than the pressure cooked flour. This might be due to the leaching out of the micronutrient during pressure cooking time. The moisture content of pressure cooked flour was found to be higher (17.84) than the raw and roasted jackbeans flour (9.91 and 6.49), respectively. The crude carbohydrate of roasted jackbeans flour was higher than the raw and pressure cooked jackbeans flour.

Table 1. Proximate composition of raw and differentially processed Jack beans flour.

\begin{tabular}{|c|c|c|c|c|c|c|}
\hline Sample & \%Moisture & \%Protein & \%Fat & \%Crude fibre & \%Ash & $\% \mathrm{CHO}$ \\
\hline Raw & $9.91 \pm 0.04^{b}$ & $19.84 \pm 0.06^{b c}$ & $1.88 \pm 0.02^{\mathrm{a}}$ & $2.07 \pm 0.02^{\mathrm{ab}}$ & $3.04 \pm 0.04^{\mathrm{ab}}$ & 63.26 \\
\hline Roasted & $6.49 \pm 0.02^{\mathrm{a}}$ & $18.63 \pm 0.04^{b}$ & $1.96 \pm 0.02^{b}$ & $1.99 \pm 0.02^{\mathrm{a}}$ & $2.97 \pm 0.01^{\mathrm{a}}$ & $67.96 \pm 0.03^{c}$ \\
\hline Pressure & $17.84 \pm 0.02^{c}$ & $16.73 \pm 0.06^{a}$ & $1.70 \pm 0.02^{\mathrm{a}}$ & $1.84 \pm 0.02^{\mathrm{a}}$ & $2.88 \pm 0.02^{\mathrm{a}}$ & $59.01 \pm 0.03^{\mathrm{a}}$ \\
\hline
\end{tabular}

cooked

All values are expressed as mean \pm SD of three replicate determinations. Mean values in the same column with different superscript are significantly different $(\mathrm{p}<0.05)$. 
Table 2. Effect of processing on the anti-nutritional activity of jackbeans flour.

\begin{tabular}{lcllll}
\hline Sample & $\begin{array}{l}\text { Tannin } \\
(\mu \mathrm{m})\end{array}$ & $\begin{array}{l}\text { Hemmaglutini } \\
\mathrm{n}(\mu \mathrm{m})\end{array}$ & $\begin{array}{l}\text { Trypsin } \\
\text { Inhibitor }(\mu \mathrm{m})\end{array}$ & $\begin{array}{l}\text { Phenolics } \\
(\mu \mathrm{m})\end{array}$ & $\begin{array}{l}\text { ConcanavalineA } \\
(\mu \mathrm{m})\end{array}$ \\
\hline Raw & $0.41 \pm 0.02^{\mathrm{a}}$ & $38.72 \pm 0.03^{\mathrm{c}}$ & $19.19 \pm 0.02^{\mathrm{c}}$ & $0.93 \pm 0.02^{\mathrm{c}}$ & $0.79 \pm 0.001^{\mathrm{c}}$ \\
Roasted & $6.49 \pm 0.02^{\mathrm{b}}$ & $0.16 \pm 0.02^{\mathrm{a}}$ & $0.40 \pm 0.02^{\mathrm{a}}$ & $\begin{array}{l}0.28 \pm 0.02^{\mathrm{a}} \\
0.06 \pm 0.001^{\mathrm{a}}\end{array}$ \\
Pressure cooked & $0.03 \pm 0.2 \mathrm{O}^{\mathrm{a}}$ & $1.41 \pm 0.03^{\mathrm{b}}$ & $3.77 \pm 0.02^{\mathrm{b}}$ & $0.52 \pm 0.02^{\mathrm{b}}$ & $0.23 \pm 0.002^{\mathrm{ab}}$ \\
\hline
\end{tabular}

All values are expressed as mean \pm SD of three replicate determinations. Mean values in the same column with different superscript are significantly different $(\mathrm{p}<0.05)$.

Processing techniques alters the antinutritional constituents of jackbeans flour as showed in Table 2. The level of tannin content of jackbeans flour was found to be lower in pressure cooked flour (0.245) than roasted and raw flour (0.295 and 0.41) respectively. The level of total free phenolics compounds of jackbeans flour was found to be lower in roasted flour (0.277) than the pressure cooked and raw jackbeans flour (0.529 and 0.925). The hemagglutinins activity was found to be lower in the roasted jackbeans flour (0.155) than the pressure cooked and the raw jackbeans flour (1.41 and 38.72) respectively. The trypsin inhibitor activity of roasted jackbeans flour was found to be lower (0.395) than that of the pressure cooked and the raw flour (3.77 and 19.19) respectively. The concanavalin A content was found to be lower in roasted jackbeans flour (0.064) than the pressure cooked and the raw flour (0.233 and 0.79) and concanavalin A was reported as one of the most important anti- nutritional factors in Canavalia ensiformis seeds (Udedibie and Carlini, 1998). However, roasting and pressure cooking has a significant effect on the level of this anti-nutritional factor. It was reported that concanavalin binds to carbohydrates of intestine and resists digestion (Putsztai, 1989).

The result of Table 3 showed that the sample with $20 \%$ pressure cooked flour supplement has the highest percentage of protein (12.53), fat (18.04), fibre (0.77) and ash content (1.45), respectively, while sample with $40 \%$ pressure cooked jackbeans flour supplement has the highest percentage of moisture content (4.12) and sample with 40\% of roasted jackbeans flour has the lowest percentage of fat (17.53), fibre (0.575), and also sample with $100 \%$ wheat flour has the lowest percentage of protein (9.43) and highest percentage of carbohydrate.

\section{Physical analysis and evaluation of Cookies \\ Thickness}

This result the thickness of cookies (Fig. 1) showed that the highest value $(36 \mathrm{~mm})$ was found in the control cookie that is made from $100 \%$ wheat flour (T4). The lowest value of $30 \mathrm{~mm}$ was found in both pressure cooked and roasted cookies; however, at 40\% substitutions of both roasted and pressured cooked cookies the thickness was $31 \mathrm{~mm}$ and $32 \mathrm{~mm}$ respectively.

The diameter of the cookies showed that highest significant value $(448 \mathrm{~mm})$ was observed for the cookies prepared from control (T2) while the lowest value was found for the cookies prepared from (To) $(421 \mathrm{~mm})$ Fig. 2. The higher the amount of roasted jackbean flour supplementation, the higher the increase in diameter.

Table 3. Nutritional qualities of the cookies.

\begin{tabular}{|c|c|c|c|c|c|}
\hline Parameters (\%) & Sample A & Sample B & Sample C & Sample D & Sample E \\
\hline Fibre & $0.72 \pm 0.02^{c}$ & $0.77 \pm 0.01^{d}$ & $0.64 \pm 0.02^{b}$ & $0.62 \pm 0.01^{\mathrm{ab}}$ & $0.58 \pm 0.02^{a}$ \\
\hline Ash & $1.32 \pm 0.01^{\mathrm{a}}$ & $1.45 \pm 0.02^{\mathrm{c}}$ & $1.29 \pm 0.02^{\mathrm{a}}$ & $1.36 \pm 0.02^{b}$ & $1.44 \pm 0.01^{\mathrm{c}}$ \\
\hline Moisture content & $3.80 \pm 0.01^{\mathrm{ab}}$ & $3.64 \pm 0.02^{\mathrm{a}}$ & $4.12 \pm 0.01^{c}$ & $3.62 \pm 0.02^{\mathrm{a}}$ & $4.04 \pm 0.02^{b c}$ \\
\hline Protein & $9.43 \pm 0.06^{\mathrm{a}}$ & $12.53 \pm 0.04^{c}$ & $11.82 \pm 0.07^{\mathrm{b}}$ & $11.70 \pm 0.08^{b}$ & $11.43^{ \pm 0.06^{b}}$ \\
\hline Fat & $17.74 \pm 0.02^{\mathrm{a}}$ & $18.04 \pm 0.01^{\mathrm{ab}}$ & $17.83 \pm 0.01^{\mathrm{a}}$ & $17.97 \pm 0.02^{\mathrm{ab}}$ & $17.53 \pm 0.02^{a}$ \\
\hline Carbohydrate & $66.99 \pm 0.03^{c}$ & $63.62 \pm 0.04^{\mathrm{a}}$ & $64.31 \pm 0.05^{\mathrm{a}}$ & $64.73 \pm 0.03^{\mathrm{ab}}$ & $64.99 \pm 0.01^{b}$ \\
\hline
\end{tabular}

All values are expressed as mean \pm SD of three replicate determinations. Sample A: $100 \%$ Wheat; Sample B: 80:20 Wheat-jackbeans pressured cooked; Sample C: 60:40 Wheat-jackbeans pressured cooked; Sample D: 80:20 Wheat-jackbeans roasted; Sample E: 60:40 Wheat-jackbeans roasted.

Mean values in the same row with different superscript are significantly different $(p<0.05)$. 


\section{Spread factor}

Highest spread factor $(50.22 \mathrm{~mm})$ was observed in the cookies prepared from 100\% wheat flour (T4) (Fig. 3). Tsen (1976) showed fortified wheat flour with soy flour isolate up to the level of $50 \%$ diminished greatly the spread factor thereby enhanced the thickness. Similar results were reported by Hoojat and Zebik (1984) in replacement of $20 \%$ and $30 \%$ navy bean, sesame seed flour decreased spread factor of the wheat flour cookies.

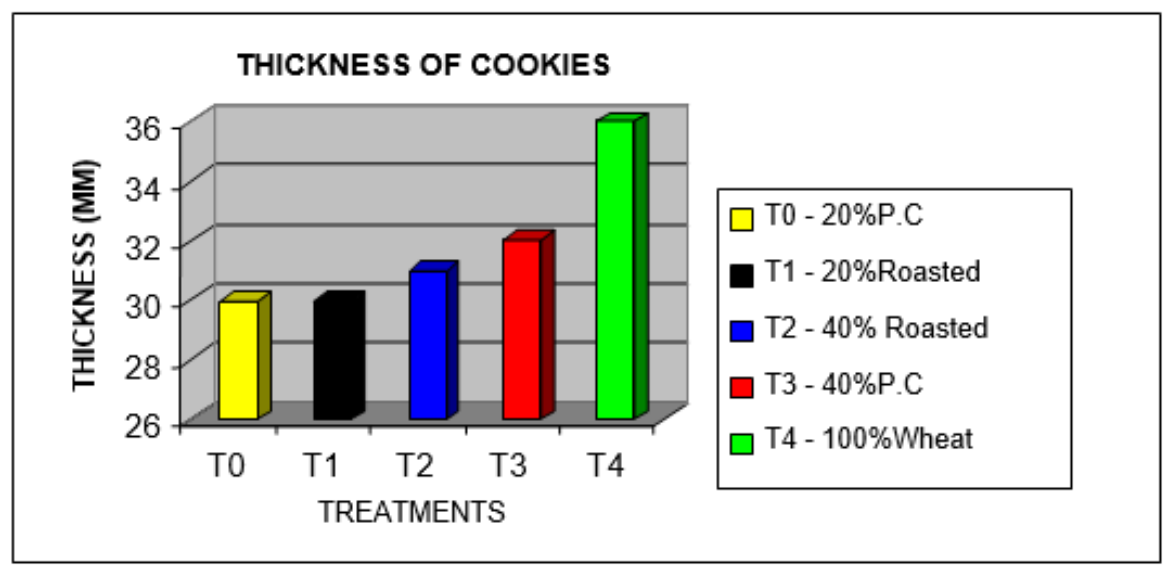

Fig. 1. Thickness of the cookies.

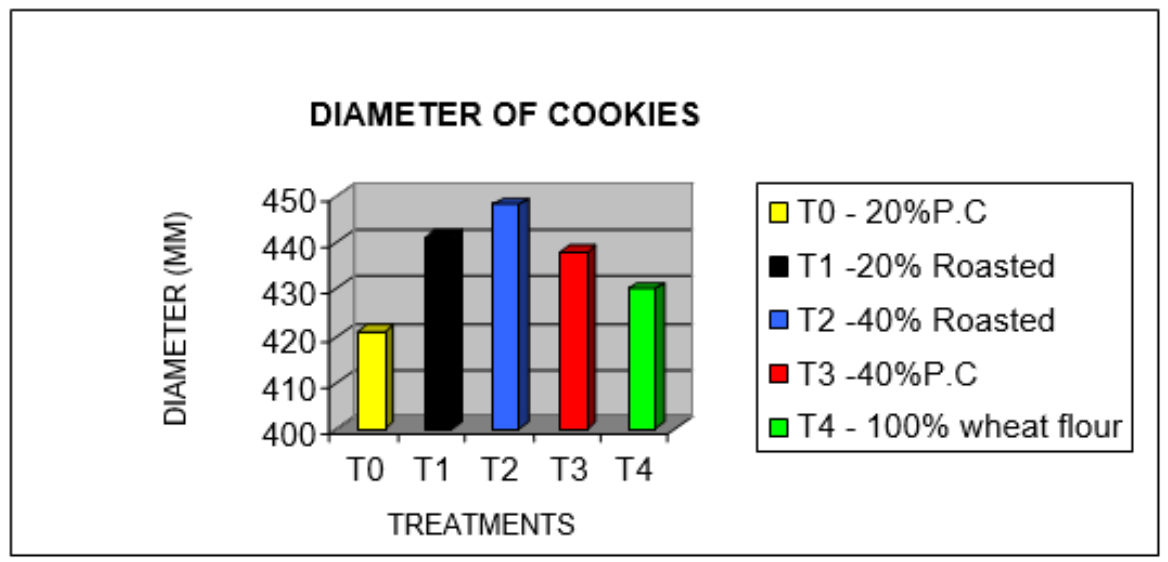

Fig. 1. Diameter of the cookies.

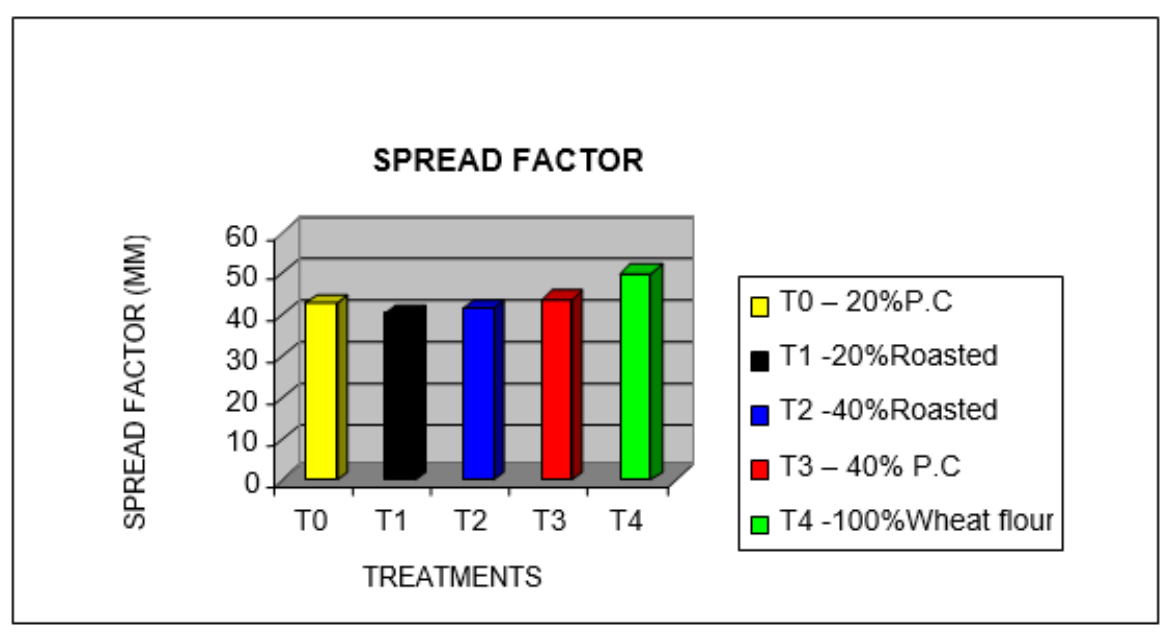

Fig. 3. Spread factor of the cookies. 
Table 4. Sensory properties of the cookies.

\begin{tabular}{llllll}
\hline Parameters (\%) & Taste & Colour & Aroma & Texture & Overall Acceptability \\
\hline Sample A & $7.5 \mathrm{a}$ & $7.7 \mathrm{a}$ & $7.0_{\mathrm{b}}$ & $6.9 \mathrm{~b}$ & $7.3 \mathrm{a}$ \\
Sample B & $7.8 \mathrm{a}$ & $7.6 \mathrm{a}$ & $7.2 \mathrm{a}$ & $7.3 \mathrm{a}$ & $7.9 \mathrm{a}$ \\
Sample C & $6.2 \mathrm{c}$ & $6.5 \mathrm{c}$ & $6.2 \mathrm{c}$ & $6.4 \mathrm{~b}$ & $6.9 \mathrm{~b}$ \\
Sample D & $7.1 \mathrm{~b}$ & $6.9 \mathrm{c}$ & $7.2 \mathrm{a}$ & $5.8_{\mathrm{c}}$ & $6.7 \mathrm{~b}$ \\
Sample E & $6.0_{\mathrm{c}}$ & $7.3 \mathrm{~b}$ & $6.8_{\mathrm{c}}$ & $5.9 \mathrm{c}$ & $5.8_{\mathrm{c}}$ \\
\hline
\end{tabular}

All values are expressed as mean \pm SD of three replicate determinations. Sample A: 100\% Wheat; Sample B: 80:20 Wheat-jackbeans pressured cooked; Sample C: 60:40 Wheat-jackbeans pressured cooked; Sample D: 80:20 Wheat-jackbeans roasted; Sample E: 60:40 Wheat-jackbeans roasted.

Mean values in the same row with different superscript are significantly different $(\mathrm{p}<0.05)$.

\section{Sensory evaluation of cookies}

\section{Colour}

The result of colour of cookies is showed in Table 4. It is evident from the result that highest score was recorded from sample prepared from 100\% wheat flour (7.7), while the lowest score was recorded for cookies prepared from 40\% pressured cooked (6.5) cookies substitution. Judges rated cookies prepared from $40 \%$ pressure cooked (6.5) and $20 \%$ roasted (6.9) with respect to colour.

\section{Aroma}

Flavour determine the consumer perception. The quality score showed significant variation in flavour among different treatments. The result indicated that the cookies prepared from $20 \%$ pressured cooked and $40 \%$ roasted flour was (7.2) respectively, significantly got the highest score for flavour while the lowest score was recorded for sample with $40 \%$ pressure cooked (6.2).

\section{Texture}

The texture of the cookies containing roasted Jackbeans flour supplement was significantly effect at alpha 0.05. Cookies prepared from 20\% pressure cooked got the score (7.3) for texture while the lowest score was obtained in the cookies produced from 40\% pressure cooked and 40\% roasted respectively 5.8 and (5.9).

\section{Taste}

Taste is the sensation of flavour perceived in the mouth and throat according to the result obtained, cookies prepared from 20\% pressure cooked and $100 \%$ whole wheat has the highest score (7.8) and 7.5) respectively while with $40 \%$ pressure cooked and $40 \%$ roasted got the lowest score (6.2) and (6.0) respectively.

\section{Overall general acceptability}

The overall acceptability of jackbeans and wheat flour is seen as indicated in Table 4. It was mainly sample with $20 \%$ pressure cooked and $100 \%$ wheat respectively (7.9 and 7.3$)$ and the lowest score was obtained from cookies produced from $40 \%$ roasted flour substitution (5.8). The result of this finding shows that the higher the level of substitution the lower the overall acceptability, this is in line with the finding of Gambus et al. (2003), Iqbal (1997), Shearer (2002), Alpers \& Sawyer-Morse (1996) Sharma et al. (1999) and Ullah (1990).

\section{Conclusion}

The results of this study indicates that jackbeans flour have potential for human feeding, judging from their proximate composition and may prove useful as a functional ingredient in cookies formulation because of their high protein, fat, fibre and ash content. In conclusion, the inclusion of jackbeans flour for the production of cookies tremendously would help to improve its nutritional qualities as this type of food can be accepted by everybody.

\section{References}

Akobundu., E.N.T., Ubbaonu, C.N and Ndupuh, C.E. (1998). Studies on the baking potentials of non-wheat composite flours. Journal of Food Science and Technology, 25:211:214

Alpers, L., \& Sawyer-Morse, M. K. (1996). Eating quality of banana nut muffins and oatmeal cookies made with ground flaxseed. Journal of the American Dietetic Association, 96(8), 794-796.

AOAC (1984). 14 $4^{\text {th }}$ edition Pg $187-188$ INC1111, North Nineteenth street suite 210, Arlington VA 222-114

AOAC (2000). Official Methods of Analysis $15^{\text {th }}$ Edition, Association of Official Analytical Chemists, Washington DC 
Balogun, A.M., Fetuga, B.L. (1986). Chemical composition of some under exploited leguminous crop seeds in Nigeria. Journal of Agricultural and Food Chemicals, 34:189-192

Bressani, R. (2002, April). Factors influencing nutritive value in food grain legumes: Mucuna compared to other grain legumes. In Food and feed from Mucuna: Current user and the way forward. Proceedings of an International Workshop (pp. 164-188).

FAO, (1995). Sorghum and millet in human nutrition Food Agricultural Organization of United Nations. Food and nutrition series No 27, Rome

Gambus H, Mikulec A and Matusz A. (2003). The Canadian muffins and hermit cookies with linseeds. Zywnosc, 10(3): 82-92.

Hoojat, P and Zebik M.E. (1984). Sugar snap cookies prepared with wheat, navy bean, sesame seed flour blends. Cereals chem., 61(1): 41-44.

Hussain, S., Anjum, F. M., Butt, M. S., Khan, M. I., \& Asghar, A. (2006). Physical and sensoric attributes of flaxseed flour supplemented cookies. Turkish Journal of Biology, 30(2), 87-92.

Iqbal, M.A. (1997). Quality aspects of biscuits containing figs in their formulation. M.Sc Thesis Dept Food Techol., Univ Agric, Faisalabad, Pakistan.

Kakade, M.L., Rackis, J.J., McGhee, J.E., Puski, G. (1974). Determination of trypsin inhibitor activity of soy products:

collaborate analysis of an improved procedure. Cereal Chemistry, 51: 376-382

Liner, I. (1953). Soyin, a toxic protein from the soybean. 1. Inhibition of rat growth. Journal of Nutrition, 49, 527-539.

Mako, A. A. (2013). Performance of West African Dwarf goats fed graded levels of sun-cured water hyacinth (Eichhornia crassipes Mart. Solms-Laubach) replacing Guinea grass. Livestock Research for Rural Development, 25(7).
Putsztai, A. 1989. Biological effects of dietary lectins. In: Recent advances of research in antinutritional factors in legumes seeds. seeds (Ed. Huismay et al.). Pudoc, Wageningen, pp 244-245.

Sharma, S., Bajwa, U., \& Nagi, H. P. S. (1999). Rheological and baking properties of cowpea and wheat flour blends. Journal of the Science of Food and Agriculture, 79(5), 657-662.

Shearer, A. E. H. (2002). Physicochemical properties of muffins prepared with various levels of flaxseed flour. Animal and Food Sciences Univ Delaware College of Agric Newark.

Sridhar, K. R., \& Seena, S. (2006). Nutritional and antinutritional significance of four unconventional legumes of the genus Canavalia-A comparative study. Food Chemistry, 99(2), 267-288.

Tsen, C.C. (1976). Regular and protein fortified biscuits from composite flours. Cereal foods world, 21:633-40.

Udedibie, A. B. I., \& Carlini, C. R. (1998). Questions and answers to edibility problem of the Canavalia ensiformis seeds-a review. Animal Feed Science and Technology, 74(2), 95-106.

Udedibie, A. B. I., \& Nkwocha, C. O. (1990). Comparative study of jackbean and jackbean as protein supplements for young broiler chicks. Nigerian Agricultural Journal, 24, 7-14.

Ullah, E. (1990). Effect of Supplementation of Matri (Lathyrus sativus) on the Quality of Biscuits. M.Sc. Thesis Dept. Food Technol, Univ Agric., Faisalabad, Pakistan. 